\title{
Analisis Faktor-Faktor yang Mempengaruhi Kinerja Perusahaan Perbankan yang Terdaftar di Bursa Efek Indonesia Periode 2015-2018
}

\author{
Irwan Abdi Nugroho*, Kartika Hendra Ts, Suhendro \\ Universitas Islam Batik Surakarta \\ *Correspondence email: irwanabdin14@gmail.com
}

\begin{abstract}
Abstrak. penelitian ini bertujuan untuk mengetahui, menguji dan menganalisis Likuiditas, Kecukupan Modal, Firm Size, Good Corporate Governance dan Profitabilitas perusahaan perbankan di Indonesia yang terdaftar di Bursa Efek Indonesia (BEI) laporan keuangan triwulan 29 perusahaan perbankan periode 2015-2018. Penelitian ini merupakan penelitian kuantitatif. Populasi dalam penelitian ini adalah perusahaan perbankan yang terdaftar pada Bursa Efek Indonesia (BEI). sampel dalam penelitian ini diambil dengan menggunakan metode purposive sampling yang memenuhi kriteria sampel yang dihendaki oleh peneliti.Data yang digunakan dalam penelitian ini adalah berupa dokumentasi. Tehnik analisis data yang digunakan dalam penelitian ini adalah analisis regresi linier berganda dan uji asumsi klasik. Berdasarkan hasil ini yang dilakukan menunjukkan bahwa Likuiditas, Kecukupan Modal, Firm Size dan Good Corporate Governance berpengaruh terhadap Profitabilitas perusahaan perbankan.
\end{abstract}

Kata kunci : Firm Size; GCG; Kecukupan Modal; Likuiditas; Profitabilitas

Abstract. This study aims to determine, test and analyze Liquidity, Capital Adequacy, Firm Size, Good Corporate Governance and Profitability of banking companies in Indonesia that are listed on the Indonesia Stock Exchange (BEI), the quarterly financial reports of 29 banking companies for the 2015-2018 period. This research is a quantitative research. The population in this study are banking companies listed on the Indonesia Stock Exchange (BEI). The sample in this study was taken using a purposive sampling method that met the sample criteria desired by the researcher. The data used in this study were in the form of documentation. The data analysis technique used in this research is multiple linear regression analysis and classical assumption test. Based on these results, what is done shows that Liquidity, Capital Adequacy, Firm Size and Good Corporate Governance affect the profitability of banking companies.

Keywords : Capital Adequacy; Firm Size; Good Corporate Governance; Liquidit; Profitability

\section{PENDAHULUAN}

Sebuah dasar prinsip kepercayaan hubungan antara nasabah dengan bank sangat diperlukan dalam dunia perbankan karena bank merupakan perusahaan industri jasa yang memberikan pelayanan jasa kepada masyarakat. Untuk membuat masyarakat semakin percaya terhadap bank, maka diperlukan kinerja keuangan yang baik oleh bank tersebut. Kinerja keuangan bank digunakan untuk menganalisis hasil kebijakan, kinerja, efisiensi, dan efektivitas perusahaan dalam hal keuangan. Hasil analisis tersebut mencerminkan efektifitas bank dalam memanfaatkan sumber daya keuangan dan lainnya untuk mendapatkan keuntungan. Evaluasi kinerja keuangan adalah ukuran subyektif untuk menilai penggunaan aset perusahaan untuk menghasilkan keuntungan. Salah satu alat ukur kinerja keuangan dapat dilihat dari rasio profitabilitas yang dihasilkan oleh bank tersebut. Semakin tinggi profitabilitas yang dihasilkan oleh bank, maka bank tersebut mempunyai kinerja keuangan yang baik. Salah satu rasio yang digunakan untuk mengukur dan membandingkan rasio profitabilitas salah satunya dengan menggunakan Return On Asset (ROA). Rasio ROA lebih sering digunakan untuk mengukur dan membandingkan rasio profitabilitas dikarenakan rasio ROA lebih menunjukkan efektifitas perusahaan dalam memperoleh keuntungan dengan memanfaatkan keseluruhan aset yang dimiliki perusahaan.

Salah satu usaha untuk meningkatkan kinerja keuangan adalah menentukan struktur modal yang akan dibuat oleh manajemen. Kebijakan dalam menentukan struktur modal menyangkut kombinasi yang optimal dari penggunaan berbagai sumber dana yang akan dipakai untuk membiayai suatu investasi dan juga untuk mendukung operasional perusahaan dalam usaha meningkatkan laba perusahaan. Struktur permodalan perlu juga dinilai dari seberapa besar kegiatan perusahaan dibiayai dengan hutang. Penggunaan hutang yang cukup tinggi akan membahayakan sebuah perusahaan sehingga perlu dilihat kecukupan modal, likuiditas dan solvabilitas (leverage) dalam menilai kemampuan perusahaan tersebut dalam membayar hutang baik itu hutang jangka pendek maupun hutang jangka panjang. Selain penggunaan hutang untuk pembiayaan operasional perusahaan, modal perusahaan perbankan dapat diperoleh dari mencari investor dan dana dari nasabah. Investor dan nasabah cenderung lebih percaya pada perbankan yang besar karena dari ukuran perusahaan yang besar menunjukkan total aset dan kapitalisasi aset yang besar sehingga investor 
merasa aman untuk menginvestasikan dana di bank tersebut. Dengan semakin besarnya dana dari investor dan nasabah maka perusahaan perbankan dapat membiayai kegiatan operasionalnya. Modal bank yang sedikit membatasi kapasitas usaha bank mengingat modal menunjukkan kemampuan bank menutup resiko-resiko usaha yang dihadapi.

Kepercayaan investor dan nasabah selain melihat ukuran perusahaan juga melihat tata kelola perusahaan yang baik atau Good Corporate Governance. Pelaksanaan Good Corporate Governance yang baik akan memberikan perlindungan kepada para pemegang saham dan kreditur, sehingga menanamkan kepercayaan pihak-pihak tersebut atas investasinya terhadap perusahaan. Penerapan prinsip-prinsip Good Corporate Governance (GCG) yang baik dapat mencegah adanya penyelewengan wewenang manajer sampai korupsi dari pihak-pihak internal perusahaan sehingga tidak merugikan investor dan nasabah yang menginvestasikan dana mereka di perusahaan tersebut. Implementasi GCG diyakini merupakan bentuk lain perusahaan dalam penegakan etika bisnis dan etika kerja yang sudah lama menjadi komitmen perusahaan, dan implementasi GCG berhubungan dengan peningkatan citra dan nilai perusahaan. Berdasarkan Surat Edaran Otoritas Jasa Keuangan No. 13 /SEOJK.03/2017, penerapan prinsip-prinsip Good Corporate Governance pada industry perbankan harus senantiasa berlandaskan pada lima prinsip dasar yaitu transparansi, akuntabilitas, pertanggungjawaban, independensi dan kewajaran.

Penelitian tentang pengaruh likuiditas, kecukupan modal, ukuran perusahaan dan Good Corporate Governance terhadap kinerja perusahaan sudah banyak dilakukan antara lain oleh Jaouad dan Lahsen (2018), Pinto et al. (2017), Ovami (2017), Tristiningtyas dan Mutaher (2013), Haryati dan Widyarti (2016), Liviawati dan Wiyati (2017), Tisna dan Agustami (2016), Dipura dan Hartomo (2016) dan Raharjo, Setiaji dan Syamsudin (2014). Hasil penelitian Jaouad dan Lahsen (2018) menunjukkan bahwa ukuran perusahaan berpengaruh positif dan signifikan terhadap ROA sedangkan kecukupan modal dan likuiditas berpengaruh positif tapi tidak signifikan terhadap ROA, penelitian tersebut juga menunjukkan bahwa ukuran perusahaan dan likuiditas berpengaruh positif tapi tidak signifikan terhadap ROE dan kecukupan modal menunjukkan pengaruh negatif tapi tidak signifikan terhadap ROE. Penelitian Pinto et al. (2017) menunjukkan bahwa leverage berpengaruh tidak signifikan terhadap ROA dan ROE, dan kecukupan modal berpengaruh tidak signifikan terhadap ROA tapi berpengaruh signifikan terhadap ROE. Ovami (2017) dalam penelitiannya menunjukkan bahwa kecukupan modal secara parsial berpengaruh positif dan signifikan terhadap kinerja keuangan (ROA) dan likuiditas secara parsial berpengaruh negatif dan tidak signifikan terhadap kinerja keuangan (ROA).

Penelitian Tristiningtyas dan Mutaher (2013) menunjukkan bahwa kecukupan modal berpengaruh positif dan signifikan terhadap ROA. Hasil penelitian Haryati dan Widyarti (2016) menunjukkan bahwa leverage dan likuiditas berpengaruh negatif dan signifikan terhadap ROA sedangkan ukuran perusahaan berpengaruh positif dan signifikan terhadap ROA. Penelitian Liviawati dan Wiyati (2017) menunjukkan bahwa kecukupan modal dan likuiditas berpengaruh tidak signifikan terhadap ROA. Penelitian isna dan Agustami (2016) menunjukkan bahwa ukuran perusahaan berpengaruh signifikan terhadap ROA dan ROE. Hasil penelitian Dipura dan Hartomo (2016) menunjukkan bahwa kecukupan modal dan likuiditas berpengaruh negatif dan signifikan terhadap ROA Hasil penelitian Dipura dan Hartomo (2016) sama dengan hasil penelitian Raharjo, Setiaji dan Syamsudin (2014) tapi berbeda dengan hasil penelitian dari Liviawati dan Wiyati (2017). Penelitian tentang pengaruh good corporate governance (GCG) terhadap ROA dilakukan Tjondro dan Wilopo (2011) dan Eksandy (2018). Hasil penelitian Tjondro dan Wilopo (2011) menunjukkan GCG memiliki pengaruh yang positif signifikan terhadap ROA sedangkan penelitian Eksandy (2018) menunjukkan GCG berpengaruh tetapi tidak signifikan terhadap kinerja keuangan perbankan syariah. Melihat hasil beberapa penelitian tentang pengaruh likuiditas, kecukupan modal, ukuran perusahaan dan good corporate governance terhadap kinerja perusahaan yang menunjukkan hasil yang berbeda-beda, maka peneliti ingin meneliti kembali pengaruh likuiditas, kecukupan modal, ukuran perusahaan dan good corporate governance terhadap kinerja perusahaan perbankan dengan periode yang berbeda yaitu periode tahun 2015-2018.

\section{METODE}

Penelitian ini merupakan penelitian deskriptif yaitu suatu metode penelitian yang ditujukan untuk menggambarkan fenomena-fenomena yang berlangsung saat ini atau pada saat lampau. Data yang digunakan berupa data sekunder yang diambil dari annual report perusahaan tahun financial 2015-2018 yang terdaftar dalam bursa efek Indonesia. Sample dipilih berdasarkan metode purposive sampling, sehingga diperoleh sampel sebanyak 116 perusahaan. 
Irwan Abdi Nugroho, Kartika Hendra Ts dan Suhendro, Analisis Faktor-Faktor yang Mempengaruhi Kinerja Perusahaan Perbankan yang Terdaftar di Bursa Efek Indonesia Periode 2015-2018

\section{HASIL DAN PEMBAHASAN}

Tabel 1

Proses Seleksi Sampel Berdasarkan Kriteria

\begin{tabular}{lrr}
\hline \multicolumn{1}{c}{ Kriteria } & $\begin{array}{c}\text { Jumlah Pelanggaran } \\
\text { Kriteria }\end{array}$ & Akumulasi \\
\hline Jumlah perusahaan subsektor bank yang terdaftar di BEI tahun 2015- & 44 \\
2018 & $(1)$ & $(1)$ \\
Perusahaan yang mengalami delisting selama tahun 2015-2018 & $(13)$ \\
Perusahaan belum menerbitkan saham tahun 2015 & 43 \\
Perusahaan memiliki data yang lengkap sesuai kebutuhan penelitian & 29 \\
Jumlah sampel selama periode penelitian (2015-2018) & 29 \\
Jumlah observasi (29 x 4 tahun) & 116 \\
\hline
\end{tabular}

Sumber : $\underline{w w w . i d x . c o . i d}$

Tabel 2

Hasil Uji Normalitas Data

\begin{tabular}{|l|ll|}
\hline Keterangan & Unstandardized Residual & \\
\hline Kolmogorov-Smirnov Z & & 1,228 \\
\hline Asymp. Sig. (2-tailed) & & 0,098 \\
\hline
\end{tabular}

Sumber: data olahan

Tabel 2 menunjukkan bahwa nilai Asymp.Sig (2-tailed) = 0,098 yang lebih besar dari level of significance $(0,05)$. Hal ini menunjukkan bahwa data sampel berdistribusi normal dan asumsi dalam statistik parametrik dapat dipenuhi.

Tabel 3

Hasil Uji Autokorelasi

\begin{tabular}{|l|r|}
\hline Model & Durbin-Watson \\
\hline 1 & 1,743 \\
\hline
\end{tabular}

Sumber: data olahan

Hasil pengujian autokorelasi dengan menggunakan Durbin-Watson dapat dilihat pada tabel 3. Dari hasil pengujian diperoleh nilai Durbin-Watson 1,743. Dari tabel Durbin Watson dengan $\mathrm{n}$ (jumlah data) $=116 \mathrm{dan} \mathrm{k}$ (jumlah variabel independen) $=4$, diperoleh nilai dL sebesar 1,6265 dan nilai dU sebesar 1,7690. Dari hasil pengujian, nilai Durbin Watson yang diperoleh $(1,743)$ berada diantara nilai dL $(1,6265)$ dan dU $(1,7690)$ sehingga dapat diambil kesimpulan bahwa tidak dapat disimpulkan terjadi autokorelasi atau tidak.

Tabel 4

Hasil Uji Heterokedastisitas

\begin{tabular}{|l|r|r|}
\hline \multicolumn{1}{|c|}{ Model } & \multicolumn{1}{c|}{ t } & \multicolumn{2}{c|}{ Sig. } \\
\hline Konstanta & 1,142 &, 256 \\
\hline LDR & 1,165 &, 247 \\
\hline CAR & 1,913 &, 058 \\
\hline SIZE & $-1,911$ &, 059 \\
\hline ROA & 1,051 &, 295 \\
\hline
\end{tabular}

Sumber: data olahan

Hasil uji heterokedastisitas dapat dilihat dalam tabel 4. Hasil pengujian menunjukkan semua variabel tidak terjadi masalah heterokedastisitas karena memiliki nilai signifikansi lebih dari 0,050.

Tabel 5

Hasil Uji Multikolinearitas

\begin{tabular}{|l|r|r|}
\hline \multicolumn{1}{|c|}{ Variabel } & Tolerance & \multicolumn{1}{c|}{ VIF } \\
\hline Likuiditas (LDR) &, 933 & 1,071 \\
\hline Kecukupan Modal (CAR) & 904 & 1,107 \\
\hline Ukuran Perusahaan (SIZE) &, 801 & 1,248 \\
\hline Kinerja Perusahaan (ROA) &, 902 & 1,109 \\
\hline
\end{tabular}

Sumber: data olahan 
Tabel 5 menunjukkan nilai VIF untuk setiap variabel tidak lebih dari 10 dan nilai tolerance lebih besar dari 0,1 sehingga dapat disimpulkan bahwa tidak terjadi gejala multikolinearitas antar variabel bebas. Dengan kata lain dinyatakan bahwa tidak ada hubungan linear atau korelasi antar variabel independen dalam model regresi pada data yang akan kita uji ini sebagai salah satu syarat yang harus dipenuhi.

Tabel 6

Statistik Deskriptif

\begin{tabular}{|c|c|c|c|c|c|}
\hline & & & & & \\
\hline & $\mathrm{N}$ & Minimum & Maximum & Mean & Std. Deviation \\
\hline LDR & 116 & 50,6100 & 108,7800 & 85,600431 & 11,5585522 \\
\hline CAR & 116 & 12,5800 & 66,4300 & 21,340172 & 6,7098092 \\
\hline Size & 116 & 27,1108 & 34,7988 & 31,074979 & 2,0873015 \\
\hline GCG & 116 & 1 & 3 & 1,99 &, 466 \\
\hline ROA & 116 & $-7,4700$ & 4,1900 & 1,449138 & 1,7690968 \\
\hline
\end{tabular}

Sumber: data olahan

Hasil uji statistik deskriptif variabel likuidits (LDR) menunjukkan nilai minimum sebesar 50,6100; nilai maksimum sebesar 108,7800; dengan rata-rata sebesar 85,600431. Hasil analisis statistik deskriptif variabel kecukupan modal (CAR) menunjukkan nilai minimum sebesar 12,5800; nilai maksimum sebesar 66,4300; dengan rata-rata sebesar 21,340172. Hasil analisis statistik deskriptif variabel ukuran perusahaan (Size) menunjukkan nilai minimum sebesar 27,1108; nilai maksimum sebesar 34,7988; dengan rata-rata sebesar 31,074979. Hasil analisis statistik deskriptif variabel good corporate governance (GCG) menunjukkan nilai minimum sebesar 1; nilai maksimum sebesar 3; dengan rata-rata sebesar 1,99. Hasil analisis statistik deskriptif variabel kinerja perusahaan (ROA) menunjukkan nilai minimum sebesar -7,4700; nilai maksimum sebesar 4,1900; dengan rata-rata sebesar 1,449138 .

Tabel 7

Hasil Uji F

\begin{tabular}{|c|c|c|c|}
\hline Model & Df & $\mathrm{F}$ & Sig. \\
\hline $\begin{array}{l}\text { Regression } \\
\text { Residual } \\
\text { Total }\end{array}$ & $\begin{array}{r}4 \\
111 \\
115\end{array}$ & 20,366 & 0,000 \\
\hline
\end{tabular}

Sumber: data olahan

Berdasarkan analisis yang telah dilakukan, diketahui besarnya nilai Sig. F 0,000 < 0,05. Kesimpulannya adalah Ho ditolak, yang artinya likuiditas, kecukupan modal, ukuran perusahaan dan good corporate governance berpengaruh secara bersama-sama (simultan) terhadap kinerja perusahaan.

Tabel 8

Hasil Uji Regresi Berganda

\begin{tabular}{|l|r|r|r|}
\hline \multicolumn{1}{|c|}{ Model } & \multicolumn{1}{c|}{ B } & \multicolumn{1}{c|}{ t } & \multicolumn{1}{c|}{ Sig } \\
\hline Konstanta & $-3,769$ & $-1,469$ &, 145 \\
\hline Likuiditas (LDR) &, 003 &, 281 &, 779 \\
\hline Kecukupan Modal (CAR) &, 063 & 3,172 &, 002 \\
\hline Ukuran Perusahaan (SIZE) &, 235 & 3,449 &, 001 \\
\hline Good Corporate Governance (GCG) & $-1,871$ & $-6,495$ &, 000 \\
\hline
\end{tabular}

Sumber : Data yang diolah

Berdasarkan hasil uji statistik t pada tabel 8 di atas dengan kesimpulan sebagai berikut :

a. Variabel likuiditas (LDR) apabila dilihat dari nilai Sig. 0,779>0,05, maka Ha ditolak. Hal ini berarti bahwa tidak terdapat pengaruh antara likuiditas terhadap kinerja perusahaan.

b. Variabel kecukupan modal (CAR) apabila dilihat dari nilai Sig. 0,002 <0,05, maka Ha diterima. Hal ini berarti bahwa terdapat pengaruh antara kecukupan modal terhadap kinerja perusahaan. Tanda koefisien regresi untuk variabel ukuran perusahaan adalah positif sebesar 0,003. Hal tersebut menunjukkan bahwa semakin besar kecukupan modal maka kinerja perusahaan akan meningkat.

c. Variabel ukuran perusahaan (SIZE) apabila dilihat dari nilai Sig. 0,001 <0,05, maka Ha diterima. Hal ini berarti bahwa terdapat pengaruh antara ukuran perusahaan terhadap kinerja perusahaan. Tanda koefisien regresi untuk variabel ukuran perusahaan adalah positif sebesar 0,235. Hal tersebut menunjukkan bahwa semakin besar ukuran perusahaan maka kinerja perusahaan akan meningkat. 
d. Variabel good corporate governance (GCG) apabila dilihat dari nilai Sig. 0,000 < 0,05, maka Ho ditolak. Hal ini berarti bahwa terdapat pengaruh antara good corporate governance terhadap kinerja perusahaan. Tanda koefisien regresi untuk variabel good corporate governance adalah negative sebesar 1,871. Hal tersebut menunjukkan

e. bahwa semakin tinggi good corporate governance suatu perusahaan maka kinerja perusahaan akan menurun.

Tabel 9

Hasil Analisis Koefisien Determinasi $\left(\mathrm{R}^{2}\right)$

\begin{tabular}{|l|r|r|rr|}
\hline Model & R & R Square & Adjusted R Square \\
\hline 1 & $0,651^{3}$ & 0,423 & 0,402 \\
\hline
\end{tabular}

Sumber : Data yang diolah

Hasil perhitungan diperoleh nilai Adjusted $R$ square sebesar 0,402. Hal itu berarti prosentase sumbangan yang diberikan variabel independen yaitu likuiditas (X1), kecukupan modal (X2), ukuran perusahaan (X3) dan good corporate governance $(\mathrm{X} 4)$ terhadap variabel dependen yaitu kinerja perusahaan $(\mathrm{Y})$ sebesar 40,2\%, sedangkan sisanya 59,8\% dijelaskan oleh faktor lain yang tidak dimasukkan dalam penelitian ini.

\section{SIMPULAN}

Likuiditas tidak berpengaruh kinerja perusahaan. Hal ini berarti besar kecilnya likuiditas tidak berpengarh terhadap kinerja perusahaan.Kecukupan modal berpengaruh positif dan signifikan terhadap kinerja perusahaan. Hal ini berarti semakin tinggi kecukupan modal suatu perbankan maka semakin tinggi kinerja perusahaan.Ukuran perusahaan berpengaruh positif dan signifikan terhadap kinerja perusahaan. Hal ini berarti semakin besar ukuran perusahaan suatu perbankan maka semakin tinggi kinerja perusahaan. Good corporate governance berpengaruh negatif dan signifikan terhadap kinerja perusahaan. Hal ini berarti semakin baik good corporate governance suatu perbankan maka semakin rendah kinerja perusahaan.

\section{DAFTAR PUSTAKA}

Akbar, Dinnul Alfian. 2013. Analisis Pengaruh Ukuran Perusahaan, Kecukupan Modal, Kualitas Aktiva Produktif (KAP) Dan Likuiditas Terhadap Kinerja Keuangan (Studi Kasus Bank Umum Syariah di Indonesia Periode 2007-2011). Forum Bisnis Dan Kewirausahaan Jurnal Ilmiah STIE MDP, 3(1), 66-82.

Aristya, Dyah. 2010. Analisis Pengaruh Ukuran Perusahaan, Kecukupan Modal, Kualitas Akiva Produktif, dan Likuiditas Terhadap Kinerja Keuangan, Semarang

Dendawijaya, Lukman. 2003. Manajemen Perbankan. Jakarta: Ghalia Indonesia

Dipura, Fajar Sukma dan Deny Dwi Hartomo. 2016. Faktor Internal dan Kinerja Perusahaan. Jurnal Bisnis dan Manajemen 16(2), 67-82.

Eksandy, Arry. 2018. Pengaruh Good Corporate Governance Terhadap Kinerja Keuangan Pada Perbankan Syari'ah Indonesia. Jurnal Akuntansi, 5(1).

Ghozali, I. 2006. Aplikasi Analisis Multivariate dengan program SPSS. Cetakan IV. Badan Penerbit Universitas Diponegoro: Semarang.

Haryati, Rina dan Endang Tri Widyarti. 2016. Pengaruh Leverage, Size, NPL, BOPO Dan LDR Terhadap Kinerja Keuangan Bank (Studi Pada Bank Umum Konvensional Yang Terdaftar Di Bursa Efek Indonesia Periode 20102014). Diponegoro Journal Of Management. 5(3), 1-13.

Hasibuan. Malayu. 2001. Dasar-Dasar Perbankan. Jakarta: Bumi Aksara

Husnan, Suad dan Endang Pujiastuti. 2002. Dasar-Dasar Manajemen Keuangan. Yogyakarta: UPP AMP YKPN

Hutagalung, Esther Novelina, Djumahir, dan Kusuma Ratnawati. 2013. Analisa Rasio Keuangan terhadap Kinerja Bank Umum di Indonesia. Jurnal Aplikasi Manajemen, 11(1), 122-130

Indarti, M.G.K. 2013. Pengaruh Corporate Governance Preception Index (CGPI), Struktur Kepemilikan, dan Ukuran Perusahaan terhadap Kinerja Keuangan. Jurnal Bisnis dan Ekonomi JBE, 20(2), 171-183.

Jaouad, Elouali dan Oubdi Lahsen. 2018. Factors Affecting Bank Performance: Empirical Evidence from Morocco. European Scientific Journal 14(34)

Kristianti, Rina Adi dan Yovin. 2016. Factors Affecting Bank Performance: Cases of Top 10 Biggest Government and Private Banks in Indonesia in 2004 - 2013. Review of Integrative Business and Economics Research. 5(4), 371378.

Liviawati dan Rita Wiyati. 2017. Faktor - Faktor yang Mempengaruhi Kinerja Perbankan Suatu Studi Pada Bank yang terdaftar di Bursa Efek Indonesia. Pekbis Jurnal, 9(3), 231-240

Mawardi, Wisnu. 2005. Analisis Faktor-Faktor Yang Mempengaruhi Kinerja Keuangan Bank Umum Di Indonesia (Studi Kasus Pada Bank Umum Dengan Total Asset Kurang Dari 1 Triliun). Jurnal Bisnis Strategi, 14(1), 8393. 
Irwan Abdi Nugroho, Kartika Hendra Ts dan Suhendro, Analisis Faktor-Faktor yang Mempengaruhi Kinerja Perusahaan

Muhammad. 2005. Manajemen Bank Syariah. Yogyakarta: UPP AMP YKPN

Nugrahanti, Y.W., dan Novia, S. 2012. Pengaruh Struktur Kepemilikan Sebagai Mekanisme Corporate Governance Terhadap Kinerja Perbankan. Jurnal Manajemen, 11(2), 151-170.

Nugraheni, Fitri dan Dody Hapsoro. 2007. Pengaruh Rasio Keuangan CAMEL, Tingkat Inflasi, Dan Ukuran Perusahaan Terhadap Kinerja Keuangan Perusahaan Perbankan Di Bursa Efek Jakarta. Wahana, 10(2), 63-80

Ovami, Debbi Chyntia. 2017. Faktor-Faktor Yang Mempengaruhi Kinerja Keuangan Bank Konvensional Pada Bursa Efek Indonesia. Jurnal Akuntansi dan Bisnis, 3(1).

Pinto, Prakash et al. 2017. An Evaluation of Financial Performance of Commercial Banks. International Journal of Applied Business and Economic Research, 15(22)

Prasnanugraha, Ponttie. 2007. Analisis Pengaruh Rasio-Rasio Keuangan Terhadap Kinerja Bank Umum Di Indonesia. Tesis, Magister Akuntansi Fakultas Ekonomi Universitas Diponegoro (Dipublikasikan)

Raharjo, Dwi Priyanto Agung, Bambang Setiaji dan Syamsudin. 2014. Pengaruh Rasio CAR, NPL, LDR, BOPO, dan NIM Terhadap Kinerja Bank Umum di Indonesia. Daya Saing, Jurnal Ekonomi Manajemen Sumber Daya, $15(2), 7-12$

Sekaran, Uma. 2000. Research Methods For Business: A Skill-Building Approach. Third Edition. New York: John Wiley \& Sons, Inc.

Siamat, Dahlan. 1999. Manajemen Lembaga Keuangan. Jakarta: Lembaga Penerbit FEUI

Simorangkir, O.P. 2004. Pengantar Lembaga Keuangan Bank Dan Non Bank. Jakarta: Ghalia Indonesia

Sugiyono. 2012. Metodologi Penelitian Bisnis. Bandung: Alfabeta.

Sukandar, P.P. 2014. Pengaruh Ukuran Dewan Direksi dan Dewan Komisaris Serta Ukuran Perusahaan Terhadap Kinerja Keuangan Perusahaan. Diponegoro Journal of Accounting, 3(3), 1-7.

Tisna, Gita Andriani dan Silviana Agustami. 2016 Pengaruh Good Corporate Governance dan Ukuran Perusahaan terhadap Kinerja Keuangan Perusahaan (Pada Perusahaan Perbankan yang Terdaftar di Bursa Efek Indonesia (BEI) Tahun 2010-2014). Jurnal Riset Akuntansi dan Keuangan, 4(2), 1035-1046.

Tjondro, David dan R. Wilopo. 2011. Pengaruh Good Corporate Governance (GCG) Terhadap Profitabilitas Dan Kinerja Saham Perusahaan Perbankan Yang Tercatat Di Bursa Efek Indonesia. Journal of Business and Banking, 1(1), 1-14.

Tristiningtyas, Vita dan Osmad Mutaher. 2013. Analisis Faktor-Faktor Yang Mempengaruhi Kinerja Keuangan Pada Bank Umum Syariah Di Indonesia. Jurnal Akuntansi Indonesia, 3(2) 131-145.

Wuryatiningsih. 2002. Bank dan Lembaga Keuangan lainnya. Jakarta:Salemba Empat 